\title{
Arterial Calcification Is Driven by RAGE in Enpp1-I- Mice
}

\author{
Denise L. Cecil Robert A. Terkeltaub \\ Department of Medicine, Rheumatology Section, VA Health Care System/UCSD, San Diego, Calif., USA
}

\section{Key Words}

Artery calcification - Receptor for advanced glycation end-products $\cdot$ Calgranulin $\cdot$ ENPP1 $\cdot$ Pit-1

\begin{abstract}
Background/Aims: Ectopic osteochondral differentiation, driven by ENPP1-catalyzed generation of the chondrogenesis and calcification inhibitor inorganic pyrophosphate $\left(\mathrm{PP}_{\mathrm{i}}\right)$, promotes generalized arterial calcification of infancy. The multiligand receptor for advanced glycation end-products (RAGE), which promotes atherosclerosis and diabetic cardiovascular and renal complications, also mediates chondrocyte differentiation in response to RAGE ligand calgranulins such as S100A11. Here, we tested RAGE involvement in ENPP1 deficiency-associated arterial calcification. Methods: Because ectopic artery calcification in Enpp1-/- mice is $\mathrm{P}_{\mathrm{i}}$ dependent and mediated by $\mathrm{PP}_{\mathrm{i}}$ deficiency, in vitro studies on effects of S100A11 and RAGE on mouse aortic explants were conducted using exogenous $\mathrm{P}_{\mathrm{i}}$, as well as alkaline phosphatase to hydrolyze ambient $\mathrm{PP}_{\mathrm{i}}$. Results: $\mathrm{S} 100 \mathrm{~A} 11$ induced cartilage-specific collagen IX/XI expression and calcification dependent on RAGE in mouse aortic explants that was inhibited by the endogenous RAGE signaling inhibitor soluble RAGE (sRAGE). Enpp1-/- aortic explants demonstrated decreased $\mathrm{P}_{\mathrm{i}}$-stimulated release of SRAGE, and increased calcification and type IX/XI collagen expression that were sup-
\end{abstract}

pressed by exogenous SRAGE and by Rage knockout. Last, Rage knockout suppressed spontaneous aortic calcification in situ in Enpp1-/- mice. Conclusion: Cultured Enpp1-/- aortic explants have decreased $\mathrm{P}_{\mathrm{i}}$-stimulated release of sRAGE, and RAGE promotes ectopic chondrogenic differentiation and arterial calcification in Enpp1-/- mice.

Copyright $\odot 2010$ S. Karger AG, Basel

\section{Introduction}

Pathologic arterial calcification commonly develops in the intima of atherosclerotic lesions, and in artery media in diabetes, hyperphosphatemic renal failure, aging, and generalized arterial calcification of infancy (GACI) [1-4]. Calcification decreases artery wall compliance [5]. Moreover, hydroxyapatite crystals can stimulate inflammation and may promote smooth muscle cell (SMC) apoptosis [6], thereby potentially modulating atherosclerotic plaque stability. Artery media calcification in diabetes and chronic kidney disease promotes tissue ischemia, and intimal calcification is a biomarker for more extensive disease and increased mortality in atherosclerosis [5].

Arterial calcification appears to be actively initiated and organized by osteochondral differentiation of intraarterial stem cells, pericytes, SMCs, and adventitial myofibroblasts $[1-3,7,8]$. Deficiency of physiologic inhibitors

\section{KARGER}

() 2010 S. Karger AG, Basel

Fax +41613061234 E-Mail karger@karger.ch www.karger.com www.karger.com/jvr
Dr. Robert A. Terkeltaub

Department of Medicine, Rheumatology Section, VA Health Care System

University of California San Diego, 3350 La Jolla Village Drive

San Diego, CA 92161 (USA)

Tel. +1 858642 3519, Fax +1 858552 7425, E-Mail rterkeltaub@ ucsd.edu 
of chondro-osseous differentiation such as the BMP-2 inhibitor matrix GLA protein (MGP) [9] can be compounded by lesion excess of BMP-2, and other inducers of chondro-osseous commitment and maturation [1-3]. Among factors promoting artery calcification are inorganic pyrophosphate $\left(\mathrm{P}_{\mathrm{i}}\right)$ generation [10] and expression of the sodium-dependent $P_{i}$ cotransporter Pit-1 in SMCs [11], as well as signaling stimulated by transglutaminase 2 and by the wnt $\beta$-catenin axis $[7,8]$.

Deficient ENPP1-catalyzed generation of the chondrogenesis and matrix calcification inhibitor $\mathrm{PP}_{\mathrm{i}}[10,12]$ promotes both GACI and the spontaneous artery calcification in Enpp1-/- mice that serve to model GACI [4, 13, 14]. Importantly, artery calcification in Enpp1-/- mice is associated with intra-arterial chondrogenic differentiation, and cultured ENPP1-deficient artery SMCs undergo accelerated chondrogenic trans-differentiation upon provision of a source of $P_{i}$ [13]. A high-phosphate diet increases artery calcification in Enpp1-/- mice and hypophosphatemia attenuates artery media calcification in Enpp1-/- (as well as Mgp-/-) mice [10]. Furthermore, survival in GACI has been linked with development of decreased serum phosphate [14], linked to phosphaturia that reflects the newly recognized physiologic role of ENPP1 in renal tubular phosphate handling $[15,16]$.

The immunoglobulin superfamily member receptor for advanced glycation end-products (RAGE) [17-22] is a widely expressed transmembrane protein that serves as a cognate receptor not only for the advanced glycation endproducts (AGEs) that accumulate in diabetic and aging tissues, but also S100 calgranulins, HMGB1, $\beta$-amyloid, advanced oxidation protein products and the leukocyte integrin Mac-1 [17-22]. RAGE not only promotes atherosclerosis and diabetic cardiovascular and renal complications [17-22], but also mediates chondrocyte differentiation $[23,24]$. Furthermore, recent studies have revealed the capacity of AGEs to induce calcification by cultured SMCs and pericytes mediated by RAGE signaling [2527]. RAGE signaling can be suppressed via ligand sequestration by endogenous secretory and endoproteolytically released soluble RAGE (sRAGE) [18, 19, 28-30]. Moreover, decreased sRAGE levels have been reported in association with certain forms of chronic inflammation $[18,19]$ and in calcific aortic valve stenosis [31].

Here, we examined effects of RAGE deficiency on aortic calcification in Enpp1-/- mice. As a model RAGE ligand for studies of cultured aortic explants, we focused on S100A11, a member of the S100/calgranulin family of small (about $10-14 \mathrm{kDa}$ ) polypeptides that function partly in cells by shuttling bound calcium and serving as mo- lecular chaperones $[17,32,33]$. S100 calgranulins, secreted by SMCs and other cells activated by stressors [17, 32, 33], can exert inflammatory cytokine functions mediated by RAGE signaling and suppressed by sRAGE $[23,24,34]$. Expression of calgranulins is a biomarker of chondrogenic differentiation $[35,36]$, and S100A11 promotes chondrocyte maturation to hypertrophy, a procalcifying differentiation state $[23,24]$. Our results reveal that S100A11 promotes $\mathrm{P}_{\mathrm{i}}$-driven artery explant calcification in the presence of $\mathrm{PP}_{\mathrm{i}}$ deficiency and that RAGE drives arterial calcification in Enpp1-/- mice.

\section{Materials and Methods}

\section{Reagents}

Unless otherwise indicated, chemical reagents were from Sigma-Aldrich. Polyclonal antibodies to S100A11 were described previously $[23,24]$, polyclonal antibodies to Pit-1 were from Alpha Diagnostic International, polyclonal antibodies to RAGE from Millipore, and polyclonal antibodies to collagen IX/XI from Calbiochem. Dr. A.M. Schmidt (Columbia University, N.Y., USA) generously provided sRAGE, validated for purity and freedom from endotoxin contamination as previously described [30].

Mouse Aorta Isolation, and Aortic Ring Organ Culture

Studies and Calcification Studies

All animal procedures were humanely performed according to an institutionally reviewed protocol. We studied previously described Enpp1-deficient mice [13] and Rage-/- mice (from Dr. A.M. Schmidt) (both established on a C57BL/6 background), with genotyping by PCR $[23,24]$. Since Enpp1-/- mice do not interbreed well and die prematurely due to the 'tiptoe walking' phenotype of severe peripheral joint fusion developing in the first few months of life [37], our breeding scheme was to first breed Enpp1-/+ mice with Rage-/- and to interbreed F1 Enpp1-/+ and Rage-/+ mice, and then to maintain and interbreed F2 mice that were Enpp1-/+ and Rage-/- in order to generate the doubleknockout mice. For assessment of the Enpp1-/- skeletal ankylosis ('tiptoe walking') phenotype, we analyzed 2-month-old animals for grip function in the forepaws and for decline in body weight characteristic of the poor self-feeding ability of this phenotype $[37,38]$. We gently lifted mice by their tails to lift their rear paws to induce gripping of the cage with the forepaws, classifying effective forepaw 'grip time' of the cage as greater or less than $3 \mathrm{~s}$.

For calcification assays, aortae were isolated and cut into 2 - to 3-mm rings, then cultured in M231 medium (Cascade Biologics) supplemented with bFGF, EGF, insulin, and 5\% FCS, as described [8], and explants were treated for $15 \mathrm{~min}$ with $0.2 \mathrm{mg} / \mathrm{ml}$ Collagenase I (Worthington) before adding $2.5 \mathrm{mmol} / \mathrm{l}$ sodium $\mathrm{P}_{\mathrm{i}}$ and 7 $\mathrm{U} / \mathrm{ml}$ alkaline phosphatase for 7 days. The explants were taken from multiple mice, and each aorta was cut into four pieces, then subjected to treatment, with the replicate value indicating how many mice were used. We measured calcification in samples decalcified in $0.6 \mathrm{~N} \mathrm{HCl}$ for $24 \mathrm{~h}$, via colorimetric free calcium determination using phenolsulfonphthalein (Bioassay Systems), and corrected for dry weight [8]. 

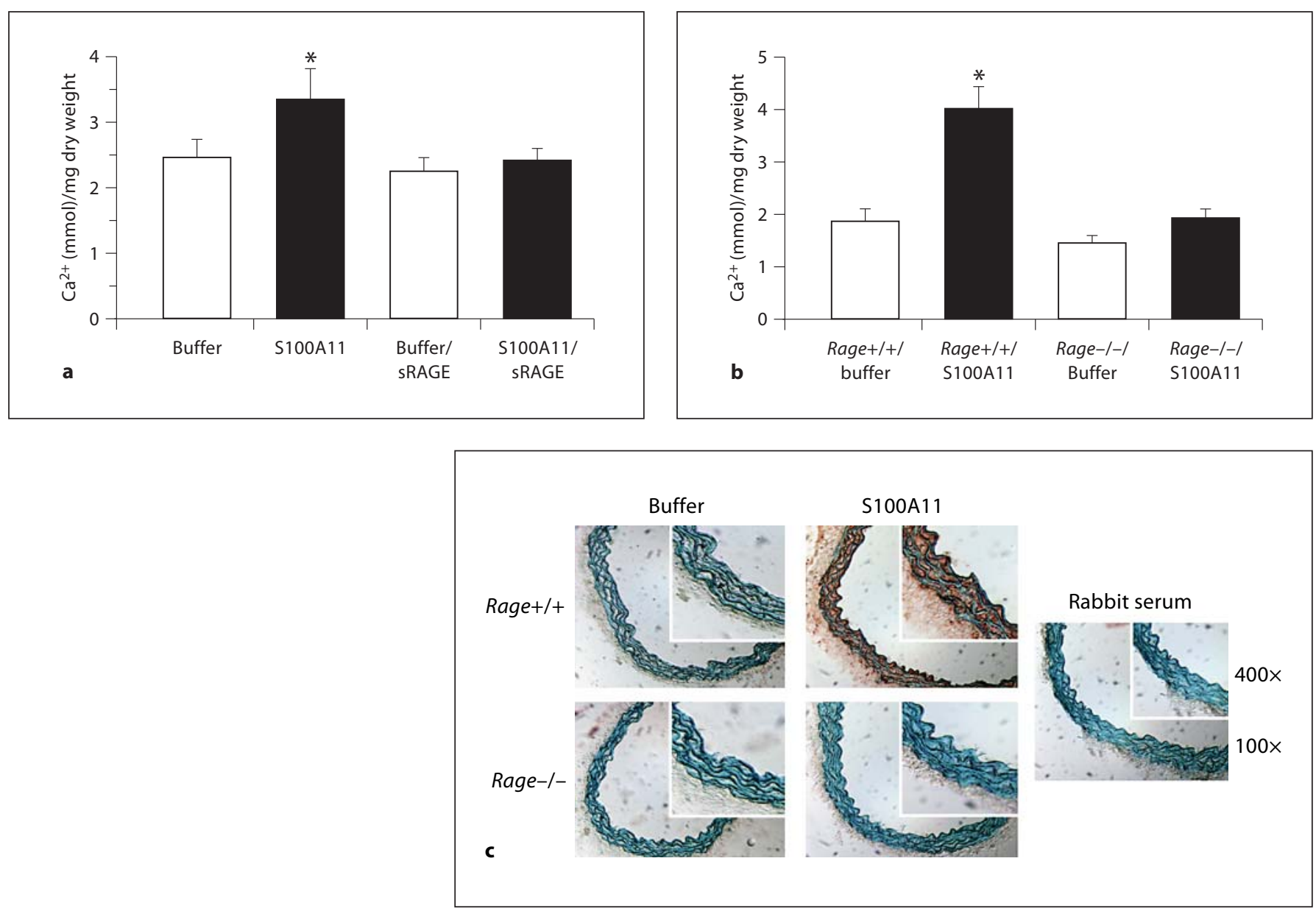

Fig. 1. Effects of S100A11, RAGE and sRAGE on calcification and chondrogenic type IX/XI collagen expression in cultured aortic explants. a Studies were done only in wild-type mouse artery explants; S100A11 (100 ng/ml) or buffer was added. In both $\mathbf{a}$ and $\mathbf{b}$, calcification was measured in mouse aortic explants of the indicated genotypes treated with collagenase for $15 \mathrm{~min}$ and then cultured for 7 days with sodium $\mathrm{P}_{\mathrm{i}}$ and alkaline phosphatase, with or

\section{Quantitative Real-Time RT-PCR}

Total RNA was isolated from aortic rings using Trizol reagent after the adventitia was removed, and reverse transcription and quantitative real-time RT-PCR were performed using the LightCycler 2.0 (Roche Diagnostics), as described [8]. Scl20a1 mRNA encoding Pit-1 was detected using primers: forward 5'-CGTGCCAAAGAAGGTGAAC-3' and reverse 5'-CACTCATGTCCATCTCAGACT-3', and mouse S100A11 mRNA primers were: forward 5'-AGCTGGACCTCAACTGT-3', and reverse 5'-GTAGGTGTGCTGGGCTC-3', and mouse Rage extracellular domain primers: forward 5'-CTGCAGGGACCCTTAGC-3', and 5'-TGGGTGGTTCCTCCTTGG-3', with relative quantification of target gene and reference (GAPDH) analysis determined the normalized target gene: GAPDH mRNA copy ratios using LightCycler Software (Version 4.0). without S100A11 (100 ng/ml) and 10-fold excess sRAGE (at a dose of $1 \mu \mathrm{g} / \mathrm{ml})(\mathbf{a ~ n}=12-14, \mathbf{b} \mathrm{n}=14-20)$. c Aortic explants, treated as above, were analyzed for chondrocyte-specific type IX/XI collagen expression (detected as brown staining, with artery media staining as blue) by immunohistochemistry at 7 days. Statistical analyses here and elsewhere were done by 2-way ANOVA.

\section{Immunohistochemistry}

Sections $(10 \mu \mathrm{m})$ of aortic ring cultures were fixed for $10 \mathrm{~min}$ in $90 \%$ methanol and $3 \%$ hydrogen peroxide and then permeabilized in $0.1 \%$ Triton X-100 for 5 min and blocked in 1\% BSA and $1 \%$ casein for 30 min. Primary antibodies were diluted 1:100 in blocking buffer and incubated at $37^{\circ} \mathrm{C}$ for $1 \mathrm{~h}$, and 3-amino-9ethylcarbazole was used to detect positive antigen staining via a Histostain Plus kit (Invitrogen). All light microscopy images were visualized on a Nikon microscope, and Nikon digital camera images were captured using ACT-2U software.

\section{SDS-PAGE/Western blotting and sRAGE ELISA}

Western blotting analyzed aliquots of $30 \mu \mathrm{g}$ protein obtained from sonicated whole aortas or precipitated from conditioned medium using $15 \%$ trichloroacetic acid, followed by separation via $10 \%$ SDS-PAGE. Horseraddish peroxidase-conjugated anti- 


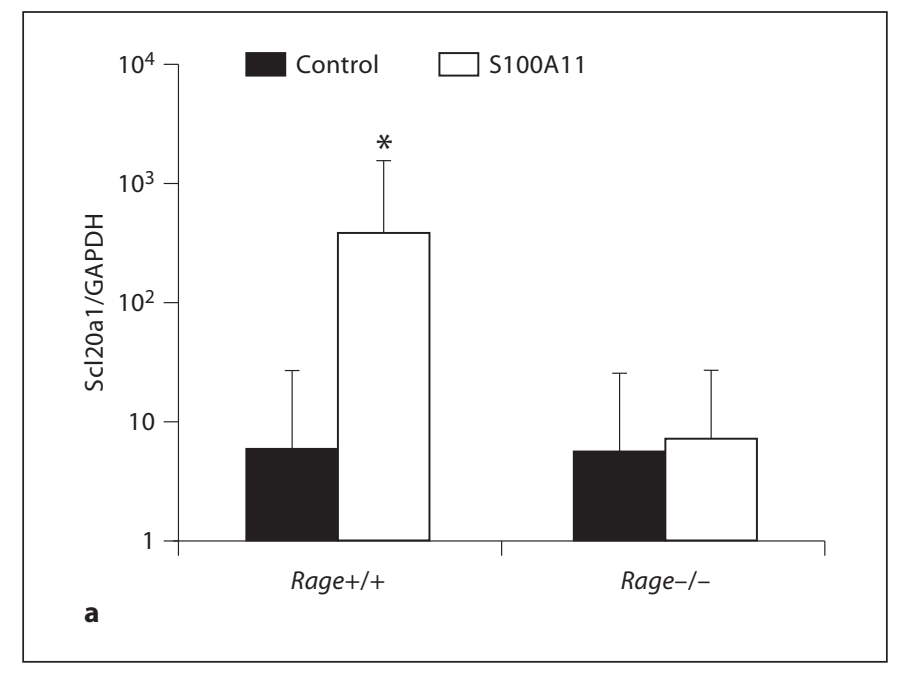

rabbit IgG $(0.11 \mu \mathrm{g} / \mathrm{ml})$ was from Pierce. Immunoreactive products were detected by enhanced chemiluminescence [24]. Quantification of conditioned medium sRAGE employed an ELISA from R\&D Systems according to the manufacturer's protocol.

Statistical Analyses

Error bars, unless otherwise indicated, represent SEM. Statistical analyses were performed by 2-way ANOVA.

\section{Results}

\section{S100A11 Induces Chondrocyte-Specific Collagen}

IX/XI Expression and Calcification in Aortic Explants Dependent on RAGE

Because ectopic artery calcification in Enpp1-/- mice is $\mathrm{P}_{\mathrm{i}}$-dependent and mediated by $\mathrm{PP}_{\mathrm{i}}$ deficiency, all in vitro studies on effects of S100A11 and RAGE on mouse aortic explants were conducted using exogenous $\mathrm{P}_{\mathrm{i}}$ as well as alkaline phosphatase to hydrolyze ambient $\mathrm{PP}_{\mathrm{i}}$. S100A11 increased the calcification of $\mathrm{P}_{\mathrm{i}} /$ alkaline phosphatase-treated mouse wild-type aortic explants (fig. 1a). The capacity of S100A11 to increase mouse aortic explant calcification was inhibited by exogenous sRAGE (at 10 fold excess to S100A11) (fig. 1a) in wild-type explants. In contrast, S100A11 failed to increase calcification in Rage-/- aortic explants (fig. 1b). Under these conditions, there was no significant difference between basal calcification (i.e. without added S100A11) in wild-type and Rage-/- artery explants (fig. 1b). S100A11 stimulated expression of chondrocyte-specific type IX/XI collagen in wild-type but not Rage-/- aortic explants (fig. 1c). S100A11 also induced Scl20a1 mRNA [8] and expression

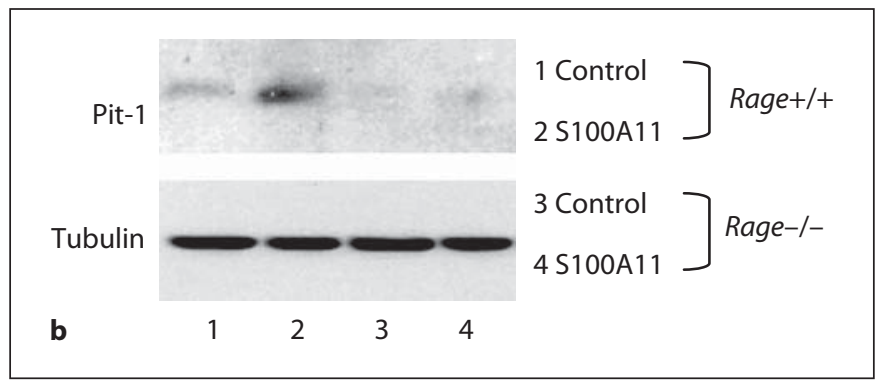

Fig. 2. Effects of S100A11 on expression of the artery calcification mediator Pit-1 in cultured aortic explants. a Scl20a1 mRNA was analyzed by $\mathrm{qPCR}\left(\mathrm{n}=11-14,{ }^{*} \mathrm{p}<0.05\right)$ at 3 days. b Pit-1 was analyzed by SDS-PAGE/Western blotting at 7 days (representative of 3 experiments) in aortic explants treated, as above, with sodium $\mathrm{P}_{\mathrm{i}}$ and alkaline phosphatase.

of its encoded protein, the sodium-dependent $\mathrm{P}_{\mathrm{i}}$ cotransporter Pit-1 [39] (a promoter of artery calcification) [11], in aortic explants (fig. 2a, b).

Calcification and Type IX/XI Collagen Expression Are Inhibited in vitro and in vivo by Rage Knockout in Enpp1-/- Aortic Explants

Aortae from 20- to 21-week-old Enpp1-/- mice manifest spontaneous calcification and features of ectopic chondrogenic differentiation in situ [13]. Here, we analyzed cultured aortic explants of 2-month-old mice. We cross-bred Rage- and Enpp1-deficient mice and observed that increased calcification and type IX/XI collagen expression in cultured $\mathrm{P}_{\mathrm{i}^{-}}$and alkaline phosphatase-treated Enpp1-/-/Rage+/+ aortic explants were not shared in Enpp1-/-/Rage-/- explants, which demonstrated responses comparable to those in Enpp1+/+/Raget/+ and Enpp1+/+/Rage-/- explants (fig. 3a, b).

Similar to the in vitro results in $\mathrm{P}_{\mathrm{i}} /$ alkaline phosphatase-treated aortic explants, spontaneous calcification in situ in 5-month-old Enpp1-/-/Rage+/+ aortae was markedly decreased by Rage knockout in age-matched Enpp1-/- aortae (fig. 3c). Nevertheless, calcification was higher $(\mathrm{p}<0.05)$ in Enpp1-/-/Rage-/- aortae in situ than in Enpp1+/+ aortae with or without Rage knockout (fig. 3c). Moreover, Rage knockout did not correct the gross skeletal phenotype and associated failure to thrive of Enpp1-/- mice, as assessed by development within months of the tiptoe-walking phenotype evidenced by significantly decreased grip strength, and significant weight loss in Enpp1-/- mice irrespective of Rage genotype (table 1). 

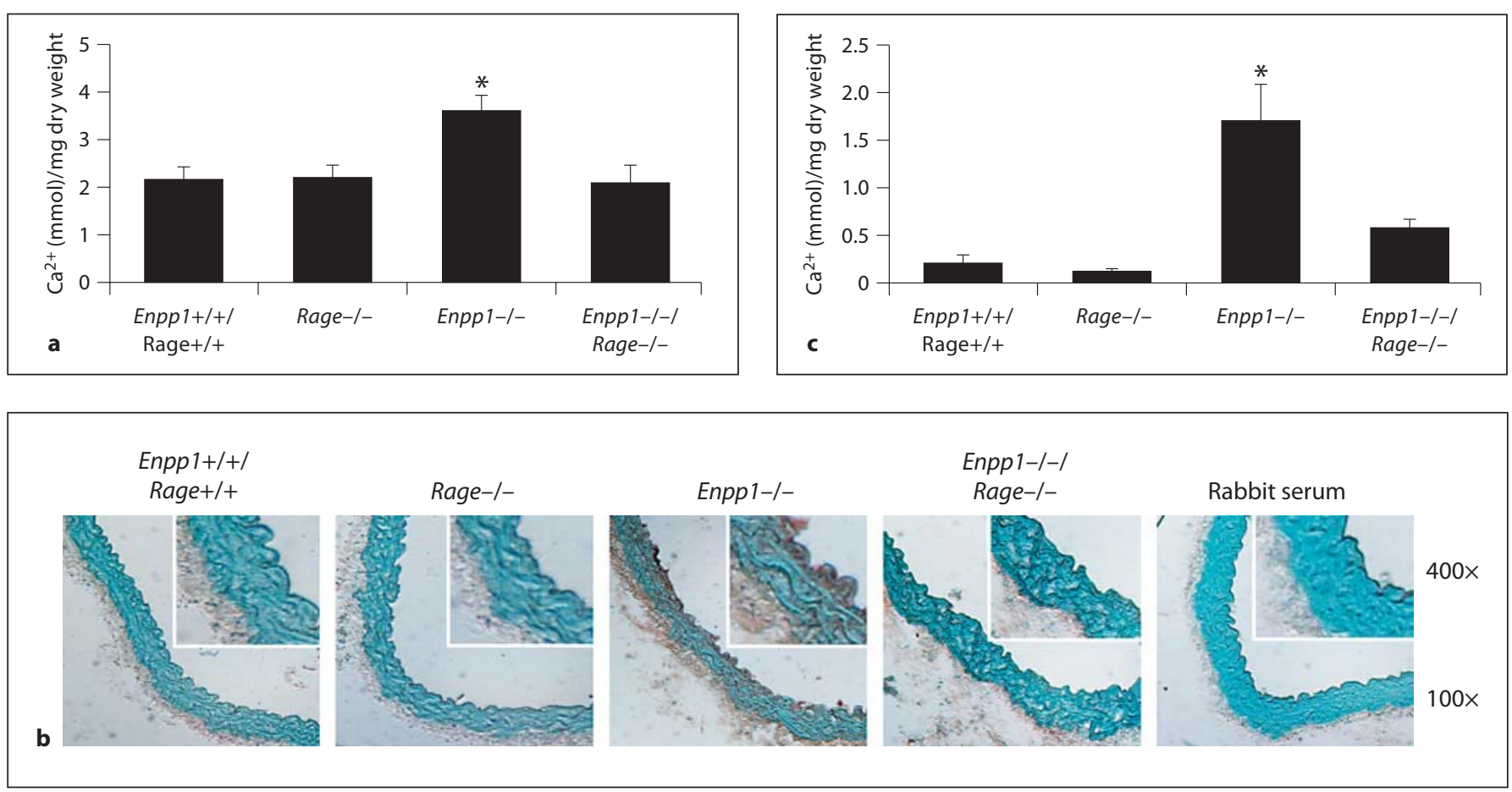

Fig. 3. Effects of RAGE on calcification in aortic samples that lack or express ENPP1. a Aortic explants from 2-month-old donors of the indicated genotypes were treated with sodium $\mathrm{P}_{\mathrm{i}}$ and alkaline phosphatase as above, and calcification was quantified at 7 days $(n=8-20)$. b Type IX/XI collagen was assessed by immunohisto- chemistry at 7 days. c Calcification in situ was analyzed in aortae removed from 5 month-old-mice $(n=11)$ without further treatment. Calcification was markedly reduced by Rage knockout in Enpp1-1- mice though remaining elevated $(\mathrm{p}<0.05)$ compared to Enpp1+/+ mice with or without Rage knockout.
Table 1. Body weights $( \pm S D)$ and grip time (measured as described in the Methods) at 2 months of age in Enpp1-/- mice with and without Rage knockout

\begin{tabular}{ccccc}
\hline Genotype & $\begin{array}{l}\text { Enpp1+/+/ } \\
\text { Rage+/+ }\end{array}$ & $\begin{array}{l}\text { Enpp1+/+/ } \\
\text { Rage-/- }\end{array}$ & $\begin{array}{l}\text { Enpp1-/-/ } \\
\text { Rage+/+ }\end{array}$ & $\begin{array}{l}\text { Enpp1-/-/ } \\
\text { Rage-/- }\end{array}$ \\
\hline $\begin{array}{l}\text { Weight, g } \\
\text { Grip time } \\
\text { <3 s }\end{array}$ & $32.3 \pm 1.5$ & $33.6 \pm 5.2$ & $25.8 \pm 0.3^{*}$ & $27.3 \pm 1.9^{*}$ \\
$>3 \mathrm{~s}$ & $0 / 108$ & $0 / 82$ & $46 / 46$ & $70 / 70$ \\
& $108 / 108^{*}$ & $82 / 82^{*}$ & $0 / 46^{*}$ & $0 / 70^{*}$ \\
\hline
\end{tabular}

${ }^{*} \mathrm{p}<0.05$.

Decreased sRAGE Release by Enpp1-/- Aortic

Explants

Cultured Enpp1-/- and wild-type aortic explants demonstrated comparable expression of S100A11 mRNA (data not shown), RAGE protein (assessed by immunohistochemistry) (fig. 4a) and Rage mRNA (screened by qPCR using primers for the RAGE extracellular domain shared by transmembrane RAGE, and endogenous secretory and proteolytically released forms of sRAGE) (data not shown). Wild-type aortic explants released significantly more sRAGE into conditioned media compared to the Enpp1-/samples cultured with or without sodium $\mathrm{P}_{\mathrm{i}}$ and alkaline phosphatase (fig. 4b). Last, exogenous sRAGE inhibited calcification by cultured $\mathrm{P}_{\mathrm{i}}$ and alkaline phosphatasetreated Enpp1-/- explants from 2-month-old mice (fig. 4c).

\section{Discussion}

In this study, whose results are schematized (fig. 5), treatment of aortic explants with the RAGE ligand S100A11 increased $\mathrm{P}_{\mathrm{i}}$-mediated calcification in a RAGEdependent manner in association with induction of Pit-1 and chondrocyte-specific type IX/XI collagen expression in vitro. Inflammation and stress-induced secretion of S100 calgranulins allow these proteins to exert inflammatory cytokine functions, mediated in large part by 

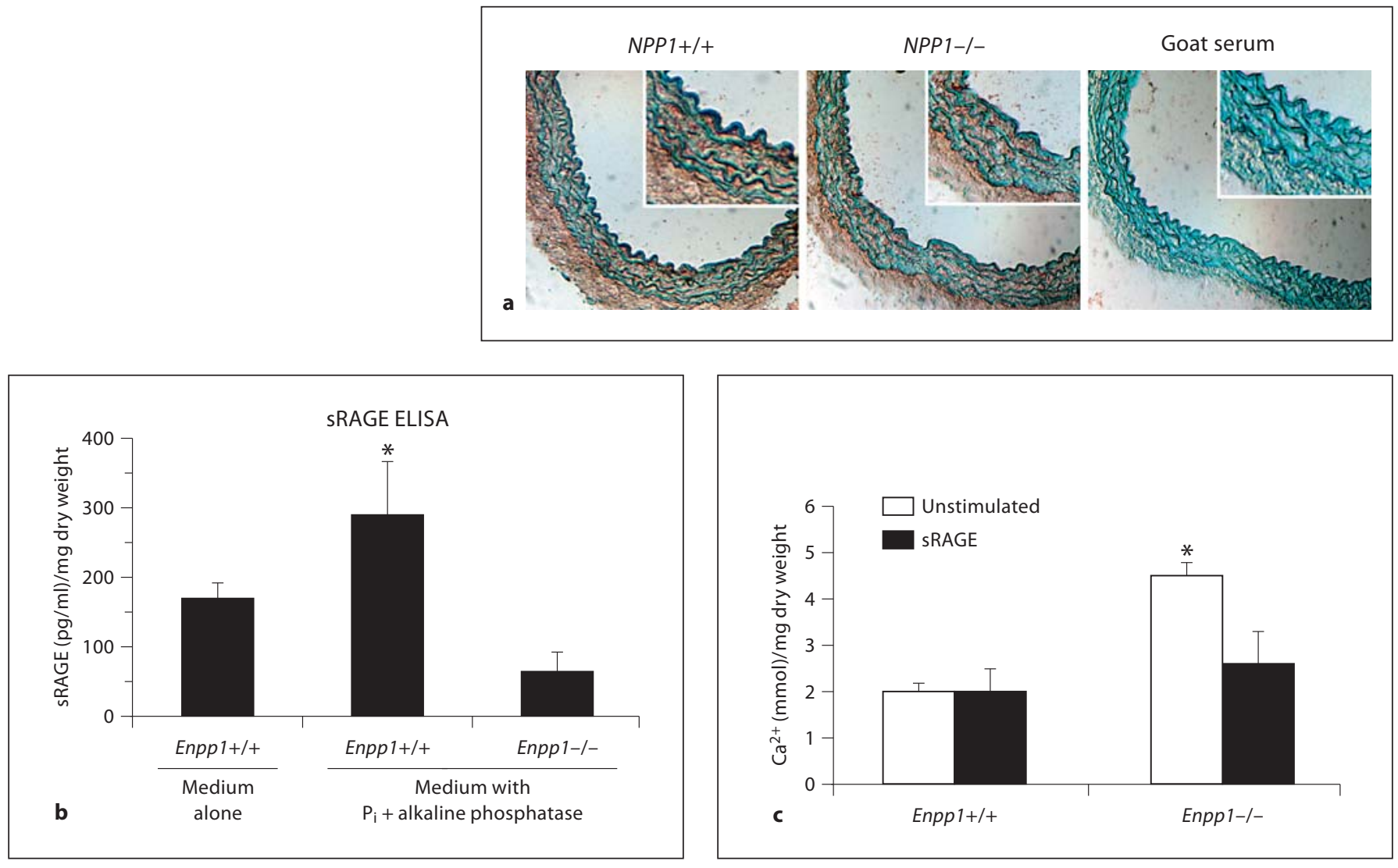

Fig. 4. RAGE and sRAGE effects and expression in cultured aortic explants that express or lack ENPP1. a Enpp1-/- and wild-type littermate aortic explants, treated with sodium $\mathrm{P}_{\mathrm{i}}$ and alkaline phosphatase, were analyzed for RAGE expression by immunohistochemistry. $\mathbf{b}$ sRAGE in conditioned media by ELISA at 3 days $(\mathrm{n}=8)$. c Explants were treated with $1 \mu \mathrm{g} / \mathrm{ml}$ sRAGE for 7 days and calcification quantified $(\mathrm{n}=8-12)$.

RAGE signaling [17-19, 34, 35]. Hence, calgranulin release illustrates a paracrine effect of inflammation that can promote artery calcification. Other examples include ectopic osteochondral differentiation stimulated by oxidative stress, generation of pro-atherogenic oxidized lipids and TNF $\alpha[1-3,5,7,40]$.

Rage knockout significantly decreased $\mathrm{P}_{\mathrm{i}}$ donor-stimulated calcification in Enpp1-/- aortic explants as well as aortic calcification in situ in Enpp1-/- mice. With ENPP1 deficiency (and decreased function of the plasma membrane $\mathrm{PP}_{\mathrm{i}}$ transporter $\mathrm{ANK}$ ) markedly decreased extracellular $\mathrm{PP}_{\mathrm{i}}$ mediates both increased chondrogenic potential of mesenchymal precursor cells and increased $\mathrm{P}_{\mathrm{i}}$ donor-stimulated osteochondral trans-differentiation of cultured arterial SMCs $[10,12,13]$. This study demonstrated not only decreased sRAGE release by $\mathrm{P}_{\mathrm{i}}$ donorstimulated aortic Enpp1-/- explants in vitro but also that exogenous sRAGE inhibited $\mathrm{P}_{\mathrm{i}}$ donor-stimulated calcifi- cation by Enpp1-/- aortic explants in vitro. Decreased sRAGE release by Enpp1-/- aortic explants was not associated with decreased RAGE expression. Calcium-regulated intramembrane proteolysis of RAGE is catalyzed by ADAM10 and $\gamma$-secretase $[28,29]$. It is possible that $\mathrm{PP}_{\mathrm{i}}$ metabolism, known to modulate expression of multiple genes $[12,13]$, influences expression of mediators of intramembrane RAGE proteolysis, and we have not yet directly assessed whether intramembrane RAGE proteolysis is altered in Enpp1-/- aortae.

We observed dissociation between effects of Rage knockout on peripheral skeletal ankylosis (manifested by paw grip dysfunction and associated wasting) and the artery calcification phenotypic features of Enpp1-/- mice in this study. Failure to thrive of Enpp1 knockout mice, which is intimately linked to peripheral joint fusion, is not suspected to contribute to artery calcification, but there was no way to test this in the scope of this study. Similar dis- 
Fig. 5. Schematic depicting the effects of ligand-induced RAGE signaling (e.g. by S100A11) and sRAGE on $\mathrm{P}_{\mathrm{i}}$-mediated artery calcification in wild-type and Enpp1/- mice. This model depicts the amplification loop by which the effects of RAGE and RAGE ligands such as S100A11 increase the capacity of the wild-type artery to calcify, in a $\mathrm{P}_{\mathrm{i}}$-mediated manner, and the $\mathrm{P}_{\mathrm{i}^{-}}$ mediated calcification pathway is known to be regulated by the sodium-dependent $\mathrm{P}_{\mathrm{i}}$ co-transporter Pit-1 (which is induced by $\mathrm{S} 100 \mathrm{~A} 11)$. The $\mathrm{P}_{\mathrm{i}}$-mediated calcification pathway in the artery is markedly enhanced by ENPP1 knockout-associated $\mathrm{PP}_{\mathrm{i}}$ deficiency, in which a secondary deficiency of sRAGE compounds the diathesis for artery calcification, since sRAGE normally inhibits the capacity of RAGE ligands to stimulate artery calcification.

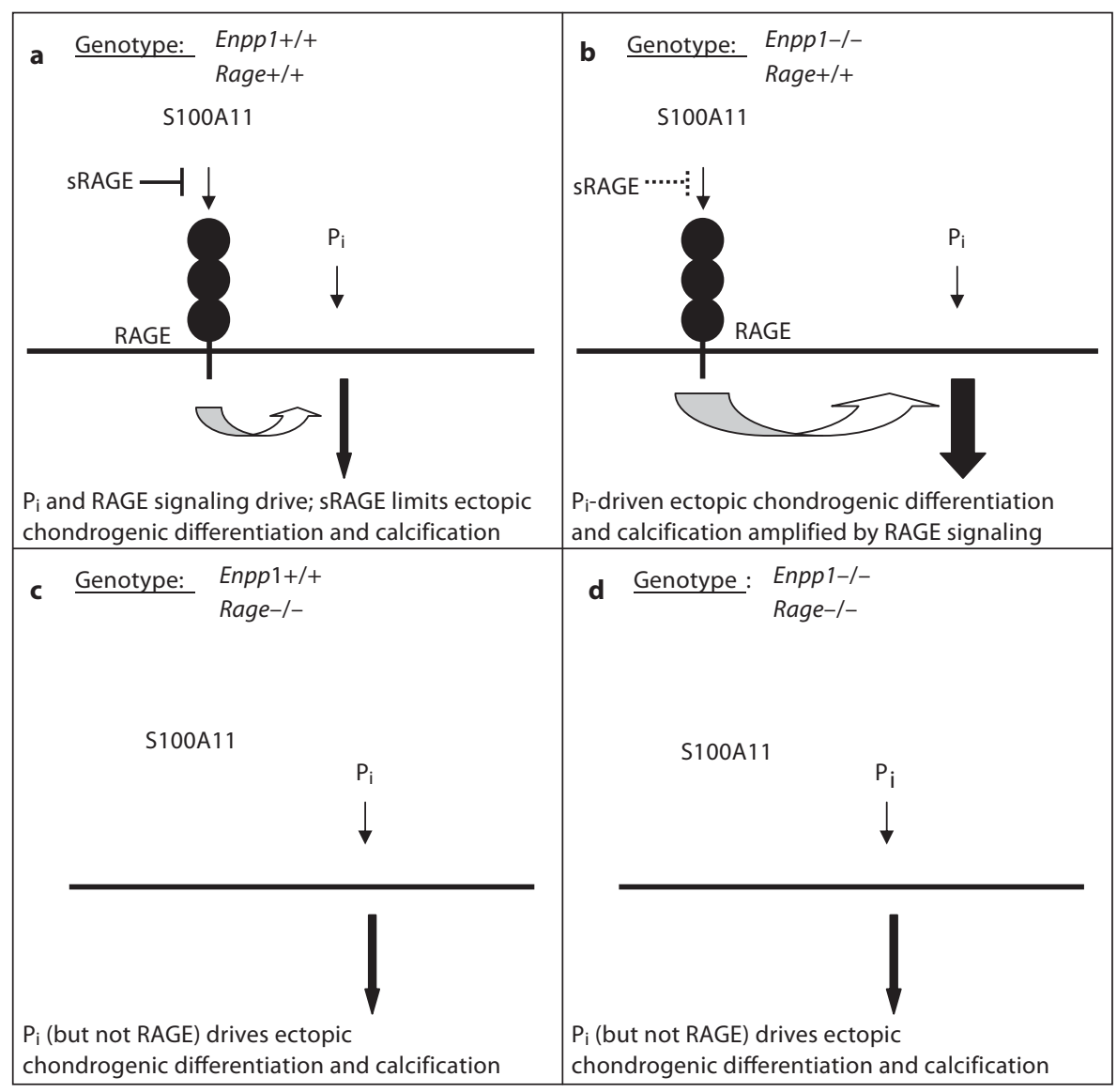

sociation between effects on artery calcification and peripheral skeletal ankylosis was previously observed with deficiency of the redox stress, inflammation, and chondrogenesis mediator Vnn1 in ank/ank mice (whose extracellular $\mathrm{PP}_{\mathrm{i}}$ deficiency state and phenotype are comparable to those of Enpp1-/- mice) [12]. The periskeletal soft-tissue calcification of ank/ank mice appears to be driven more by ectopic osteoblastic than chondrocytic differentiation and function, whereas ectopic chondrogenic differentiation appears essential to artery media calcification in ank/ank mice [12]. In this context, RAGE supports maintenance of normal bone mass in mice by modulating osteoclast function, and Rage- $/$ - mice demonstrate increased bone mass $[41,42]$. As such, in Enpp1-/- mice, loss of contribution of RAGE signaling to osteoclast differentiation $[41,42]$ could support development of pathologic osteoblast-driven ectopic calcification in periskeletal soft tissues.

This study established direct effects of S100A11 and RAGE on calcification and chondrocyte-specific collagen expression in isolated aortic explants. However, one limitation of the work is that we did not rule out additional effects of Rage knockout on the bone-vascular axis [43], via altered bone turnover, with the potential to impact on artery calcification. Other limitations included the focus on single models of in vitro and in vivo calcification. For example, we have not yet assessed the effects of RAGE in artery calcification driven by MGP deficiency, vitamin D excess, or atherosclerosis. In this light, diabetes-associated artery media calcification in mice and human atherosclerotic intimal calcification appear to be driven more by ectopic osteoblastic rather than chondrocytic differentiation [7]. Three recent studies have demonstrated that AGEs promote calcification by cultured vascular cells [25-27]. Here, we concentrated on artery explants, on mechanisms pertinent to GACI, and on a single RAGE ligand (S100A11), and not on potential effects of the multiple RAGE ligands (e.g. AGEs, HMGB1, and calgranulins other than S100A11) pertinent to arterial disease in aging, diabetes, atherosclerosis, and renal failure [17-22, 44-48]. We also have not yet determined whether alternative receptors for S100A11 such as CD36 [49] modulate artery calcification. Last, S100A11 stimulates chondrocyte-me- 
diated extracellular matrix catabolism [23, 24], and we have not yet examined the potential role of RAGE signaling in arterial extracellular matrix catabolism, which mediates SMC differentiation and calcification [50, 51].

In conclusion, the RAGE ligand S100A11 promotes $\mathrm{P}_{\mathrm{i}}$ donor-stimulated artery calcification in vitro. Moreover, RAGE is needed to drive full expression of pathologic artery calcification in an animal model of GACI, the Enpp1-/- mouse, whose aortic explants demonstrate decreased sRAGE release in vitro. Our results suggest that factors that promote shedding of sRAGE could exert substantial effects on artery calcification. In this light, release of sRAGE is associated with (and a potential biomarker of) ongoing inflammation [28] and the RAGE ligand HMGB1 stimulates shedding of sRAGE [29]. Hypophosphatemia is linked with survival beyond infancy in GACI [14], and attenuates ectopic calcification in both extracellular $\mathrm{PP}_{\mathrm{i}}$-deficient and $M g p-/-$ mice [10]. Nevertheless, deleterious systemic effects of hypophosphatemia impose limits on therapeutic serum phosphate lowering to suppress GACI. Since RAGE deficiency promotes lung fibrosis [52], it is conceivable that Rage knockout could have adverse consequences in GACI, in which, not simply calcification at the internal elastic lamina, but also marked myointimal proliferation and arterial fibrosis, are found in occluded vessels [4]. Nevertheless, antagonism of cellular RAGE signaling, for example via increasing sRAGE levels, appears to merit investigation as a potential therapeutic approach to inhibition of artery media calcification in GACI. Furthermore, RAGE may be a molecular target in other diseases associated with pathologic arterial calcification.

\section{Acknowledgements}

R.A.T. is supported by the VA Research Service and NIH (HL077360, HL087252).

\section{References}

1 Demer LL, Tintut Y: Vascular calcification: pathobiology of a multifaceted disease. Circulation 2008;117:2938-2948.

2 Shao JS, Cai J, Towler DA: Molecular mechanisms of vascular calcification: lessons learned from the aorta. Arterioscler Thromb Vasc Biol 2006;26:1423-1430.

3 El-Abbadi M, Giachelli CM: Mechanisms of vascular calcification. Adv Chronic Kidney Dis 2007; 14:54-66

4 Rutsch F, Ruf N, Vaingankar S, Toliat MR, Suk A, Höhne W, Schauer G, Lehmann M, Roscioli T, Schnabel D, Epplen JT, Knisely A, Superti-Furga A, McGill J, Filippone M, Sinaiko AR, Vallance H, Hinrichs B, Smith W, Ferre M, Terkeltaub R, Nürnberg P: Mutations in ENPP1 are associated with 'idiopathic' infantile arterial calcification. Nat Genet 2003;34:379-381.

-5 Abedin M, Tintut Y, Demer LL: Vascular calcification: mechanisms and clinical ramifications. Arterioscler Thromb Vasc Biol 2004;24:1161-1170.

-6 Ewence AE, Bootman M, Roderick HL, Skepper JN, McCarthy G, Epple M, Neumann M, Shanahan CM, Proudfoot D: Calcium phosphate crystals induce cell death in human vascular smooth muscle cells: a potential mechanism in atherosclerotic plaque destabilization. Circ Res 2008;103:28-34.

$\checkmark 7$ Al-Aly Z, Shao JS, Lai CF, Huang E, Cai J, Behrmann A, Cheng SL, Towler DA: Aortic Msx2-Wnt calcification cascade is regulated by TNF- $\alpha$-dependent signals in diabetic Ldlr-/- mice. Arterioscler Thromb Vasc Bio 2007;27:2589-2596.
8 Johnson KA, Polewski M, Terkeltaub RA: Transglutaminase 2 is central to induction of the arterial calcification program by smooth muscle cells. Circ Res 2008;102:529-537.

$\checkmark 9$ El-Maadawy S, Kaartinen MT, Schinke T, Murshed M, Karsenty G, McKee MD: Cartilage formation and calcification in arteries of mice lacking matrix Gla protein. Connect Tissue Res 2003;44(suppl 1):272-278.

10 Murshed M, Harmey D, Millán JL, McKee MD, Karsenty G: Unique coexpression in osteoblasts of broadly expressed genes accounts for the spatial restriction of ECM mineralization to bone. Genes Dev 2005; 19 : 1093-1104.

11 Li X, Yang HY, Giachelli CM: Role of the sodium-dependent phosphate cotransporter, Pit-1, in vascular smooth muscle cell calcification. Circ Res 2006;98:905-912.

12 Johnson KA, Yao W, Lane NE, Naquet P, Terkeltaub RA: Vanin-1 pantetheinase drives increased chondrogenic potential of mesenchymal precursors in ank/ank mice. Am J Pathol 2008;172:440-453.

13 Johnson K, Polewski M, van Etten D, Terkeltaub R: Chondrogenesis mediated by $\mathrm{PP}_{\mathrm{i}}$ depletion promotes spontaneous aortic calcification in NPP1-/- mice. Arterioscler Thromb Vasc Biol 2005;25:686-691.

14 Rutsch F, Böyer P, Nitschke Y, Ruf N, LorenzDeperieux B, Wittkampf T, Weissen-Plenz G, Mughal Z, Gregory J, Davies J, Loirat C, Strom T, Schnabel D, Nürnberg P, Terkeltaub $\mathrm{R}$; and the GACI Study Group: Hypophosphatemia, hyperphosphaturia and bisphosphonate treatment are associated with sur- vival beyond infancy in generalized arterial calcification of infancy. Circ Cardiovasc Genet 2008;1:133-140.

15 Lorenz-Depiereux B, Schnabel D, Tiosano D, Häusler G, Strom TM: Loss-of-function ENPP1 mutations cause both generalized arterial calcification of infancy and autosomalrecessive hypophosphatemic rickets. Am J Hum Genet 2010;86:267-272.

16 Levy-Litan V, Hershkovitz E, Avizov L, Leventhal N, Bercovich D, Chalifa-Caspi V, Manor E, Buriakovsky S, Hadad Y, Goding J, Parvari R: Autosomal-recessive hypophosphatemic rickets is associated with an inactivation mutation in the ENPP1 gene. Am J Hum Genet 2010;86:273-278.

17 Spiekerkoetter E, Guignabert C, de Jesus Perez V, Alastalo TP, Powers JM, Wang L, Lawrie A, Ambartsumian N, Schmidt AM, Berryman M, Ashley RH, Rabinovitch M: S100A4 and bone morphogenetic protein-2 codependently induce vascular smooth muscle cell migration via phospho-extracellular signal-regulated kinase and chloride intracellular channel 4. Circ Res 2009;105: 639-647.

- 18 Heizmann CW, Ackermann GE, Galichet A: Pathologies involving the S100 proteins and RAGE. Subcell Biochem 2007;45:93-138.

19 Ramasamy R, Yan SF, Herold K, Clynes R, Schmidt AM: Receptor for advanced glycation end products: fundamental roles in the inflammatory response: winding the way to the pathogenesis of endothelial dysfunction and atherosclerosis. Ann NY Acad Sci 2008; 1126:7-13. 
-20 Yan SF, Ramasamy R, Schmidt AM: Mechanisms of disease: advanced glycation endproducts and their receptor in inflammation and diabetes complications. Nat Clin Pract Endocrinol Metab 2008;4:285-293.

-21 Soro-Paavonen A, Watson AM, Li J, Paavonen K, Koitka A, Calkin AC, Barit D, Coughlan MT, Drew BG, Lancaster GI, Thomas M, Forbes JM, Nawroth PP, Bierhaus A, Cooper ME, Jandeleit-Dahm KA: Receptor for advanced glycation end products (RAGE) deficiency attenuates the development of atherosclerosis in diabetes. Diabetes 2008;57:2461-2469.

-22 Harja E, Bu DX, Hudson BI, Chang JS, Shen X, Hallam K, Kalea AZ, Lu Y, Rosario RH, Oruganti S, Nikolla Z, Belov D, Lalla E, Ramasamy R, Yan SF, Schmidt AM: Vascular and inflammatory stresses mediate atherosclerosis via RAGE and its ligands in apoE-/mice. J Clin Invest 2008;118:183-194.

-23 Cecil DL, Terkeltaub R: Transamidation by transglutaminase 2 transforms S100A11 calgranulin into a procatabolic cytokine for chondrocytes. J Immunol 2008;180:83788385.

-24 Cecil DL, Johnson K, Rediske J, Lotz M, Schmidt AM, Terkeltaub R: Inflammationinduced chondrocyte hypertrophy is driven by receptor for advanced glycation end products. J Immunol 2005; 175:8296-8302.

-25 Yamagishi S, Fujimori H, Yonekura H, Tanaka N, Yamamoto $\mathrm{H}$ : Advanced glycation endproducts accelerate calcification in microvascular pericytes. Biochem Biophys Res Commun 1999;258:353-357.

-26 Ren X, Shao H, Wei Q, Sun Z, Liu N: Advanced glycation end-products enhance calcification in vascular smooth muscle cells. J Int Med Res 2009;37:847-854.

-27 Tanikawa T, Okada Y, Tanikawa R, Tanaka Y: Advanced glycation end products induce calcification of vascular smooth muscle cells through RAGE/p38 MAPK. J Vasc Res 2009; 46:572-580.

28 Galichet A, Weibel M, Heizmann CW: Calcium-regulated intramembrane proteolysis of the RAGE receptor. Biochem Biophys Res Commun 2008;370:1-5.

-29 Park L, Raman KG, Lee KJ, Lu Y, Ferran LJ Jr, Chow WS, Stern D, Schmidt AM: Suppression of accelerated diabetic atherosclerosis by the soluble receptor for advanced glycation endproducts. Nat Med 1998;4:10251031.

-30 Raucci A, Cugusi S, Antonelli A, Barabino SM, Monti L, Bierhaus A, Reiss K, Saftig P, Bianchi ME: A soluble form of the receptor for advanced glycation endproducts (RAGE) is produced by proteolytic cleavage of the membrane-bound form by the sheddase a disintegrin and metalloprotease 10 (ADAM10). FASEB J 2008;22:3716-3727.
31 Basta G, Corciu AI, Vianello A, Del Turco S, Foffa I, Navarra T, Chiappino D, Berti S, Mazzone A: Circulating soluble receptor for advanced glycation end-product levels are decreased in patients with calcific aortic valve stenosis. Atherosclerosis 2010 [Epub ahead of print].

32 Santamaria-Kisiel L, Rintala-Dempsey AC, Shaw GS: Calcium-dependent and -independent interactions of the $\$ 100$ protein family. Biochem J 2006;396:201-214.

33 Shimamoto S, Takata M, Tokuda M, Oohira F, Tokumitsu H, Kobayashi R: Interactions of S100A2 and S100A6 with the tetratricopeptide repeat proteins, Hsp90/Hsp70-organizing protein and kinesin light chain. J Biol Chem 2008;283:28246-28258.

34 Donato R: RAGE: a single receptor for several ligands and different cellular responses: the case of certain S100 proteins. Curr Mol Med 2007;7:711-724.

35 Yammani RR, Carlson CS, Bresnick AR, Loeser RF: Increase in production of matrix metalloproteinase 13 by human articular chondrocytes due to stimulation with S100A4: role of the receptor for advanced glycation end products. Arthritis Rheum 2006 54:2901-2911.

36 Wolff DA, Stevenson S, Goldberg VM: S-100 protein immunostaining identifies cells expressing a chondrocytic phenotype during articular cartilage repair. J Orthop Res 1992; 10:49-57.

37 Johnson K, Goding J, Van Etten D, Sali A, Hu SI, Farley D, Krug H, Hessle L, Millán JL, Terkeltaub R: Linked deficiencies in extracellular $\mathrm{PP}_{\mathrm{i}}$ and osteopontin mediate pathologic calcification associated with defective PC-1 and ANK expression. J Bone Miner Res 2003;18:994-1004.

38 Okawa A, Nakamura I, Goto S, Moriya H Nakamura Y, Ikegawa S: Mutation in Npps in a mouse model of ossification of the posterior longitudinal ligament of the spine. Nat Genet 1998;19:271-273.

39 Cecil DL, Rose DM, Terkeltaub R, Liu-Bryan R: Role of interleukin- 8 in PiT-1 expression and CXCR1-mediated inorganic phosphate uptake in chondrocytes. Arthritis Rheum 2005;52:144-154.

40 Parhami F, Morrow AD, Balucan J, Leitinger N, Watson AD, Tintut Y, Berliner JA, Demer LL: Lipid oxidation products have opposite effects on calcifying vascular cell and bone cell differentiation. A possible explanation for the paradox of arterial calcification in osteoporotic patients. Arterioscler Thromb Vasc Biol 1997;17:680-687.

41 Zhou Z, Immel D, Xi CX, Bierhaus A, Feng X, Mei L, Nawroth P, Stern DM, Xiong WC: Regulation of osteoclast function and bone mass by RAGE. J Exp Med 2006;203:10671080 .
42 Ding KH, Wang ZZ, Hamrick MW, Deng ZB, Zhou L, Kang B, Yan SL, She JX, Stern DM, Isales CM, Mi QS: Disordered osteoclast formation in RAGE-deficient mouse establishes an essential role for RAGE in diabetes related bone loss. Biochem Biophys Res Commun 2006;340:1091-1097.

43 Towler DA, Shao JS, Cheng SL, Pingsterhaus JM, Loewy AP: Osteogenic regulation of vascular calcification. Ann NY Acad Sci 2006; 1068:327-333.

44 Ehlermann P, Eggers K, Bierhaus A, Most P, Weichenhan D, Greten J, Nawroth PP, Katus HA, Remppis A: Increased proinflammatory endothelial response to S100A8/A9 after preactivation through advanced glycation end products. Cardiovasc Diabetol 2006;5:6.

45 Reddy MA, Li SL, Sahar S, Kim YS, Xu ZG, Lanting L, Natarajan R: Key role of Src kinase in S100B-induced activation of the receptor for advanced glycation end products in vascular smooth muscle cells. J Biol Chem 2006;281:13685-13693

46 Bobryshev YV, Babaev VR, Iwasa S, Lord RS, Watanabe T: Atherosclerotic lesions of apolipoprotein E deficient mice contain cells expressing S100 protein. Atherosclerosis 1999; 143:451-454.

47 Bobryshev YV, Lord RS: S-100 positive cells in human arterial intima and in atherosclerotic lesions. Cardiovasc Res 1995;29:689696.

48 Inoue K, Kawahara K, Biswas KK, Ando K, Mitsudo K, Nobuyoshi M, Maruyama I: HMGB1 expression by activated vascular smooth muscle cells in advanced human atherosclerosis plaques. Cardiovasc Pathol 2007; 16:136-143.

$\checkmark 49$ Cecil DL, Appleton CT, Polewski MD, Mort JS, Schmidt AM, Bendele A, Beier F, Terkeltaub R: The pattern recognition receptor CD36 is a chondrocyte hypertrophy marker associated with suppression of catabolic responses and promotion of repair responses to inflammatory stimuli. J Immunol 2009; 182:5024-5031

50 Basalyga DM, Simionescu DT, Xiong W, Baxter BT, Starcher BC, Vyavahare NR: Elastin degradation and calcification in an abdominal aorta injury model: role of matrix metalloproteinases. Circulation 2004;110: 3480-3487.

51 Qin X, Corriere MA, Matrisian LM, Guzman RJ: Matrix metalloproteinase inhibition attenuates aortic calcification. Arterioscler Thromb Vasc Biol 2006;26:1510-1516.

52 Englert JM, Hanford LE, Kaminski N, Tobolewski JM, Tan RJ, Fattman CL, Ramsgaard L, Richards TJ, Loutaev I, Nawroth PP, Kasper M, Bierhaus A, Oury TD: A role for the receptor for advanced glycation end products in idiopathic pulmonary fibrosis. Am J Pathol 2008;172:583-591. 